\title{
Using Restriction-Site Variation of PCR-Amplified 18S Ribosomal RNA Gene for Phylogenetic Analysis of Hymenolepis spp.
}

\author{
Mohammed H. Awwad, Gehan H. Lashien and Sahar M. Abou El kheir \\ Department of Zoology, Faculty of Science, Zagazig University, Benha Branch
}

\begin{abstract}
Hymenolepis spp. infections are often asymptomatic, especially in light cases. Heavy infections can induce enteritis with nausea and vomiting, diarrhea, abdominal pain, and dizziness. Genetic therapy is the most future promising trend for treatment and prevention so, a genotype map of different parasite on microorganisms must be done. A simple and rapid polymerase chain reaction/restriction fragment length polymorphisms (PCR/RFLPs) assay, using the common restriction endonucleases HindIII, BglI, EcoRI, BanII, SacII and SstII, is described to illustrate the genetic structure of both Hymenolepis species. All restriction endonucleases have been used to differentiate between both species and based on $\sim 2200$ bp long sequence of the 18S ribosomal RNA gene.

$H$. nana and $H$. diminuta were undifferentiated when their 18S rRNA genes digested with HindIII restriction endonuclease. The two Hymenolepis were welldifferentiated when their $18 \mathrm{~S}$ ribosomal RNA genes were digested with $B g 1 \mathrm{I}$ and EcoRI restriction endonucleases. It's clear observed that BanII, SacII and SstII restriction enzymes could be used as a genetic marker for $H$. nana when the enzymes uniquely fragmented the 18S rRNA gene without digesting the gene of $H$. diminuta.
\end{abstract}

Key words: Phylogeny, Hymenolepis, PCR/RFLPs, 18S rRNA gene.

\section{Introduction}

Intestinal parasites are widely prevalent in developing countries, probably due to poor sanitation and inadequate personal hygiene. It is estimated that as much as $60 \%$ of the world's population is infected with gut parasites, which may play a role in morbidity due to intestinal infections (WHO, 1987 and Gagandeep et al., 1998). In addition, the common practice of keeping wild animals as pets, particularly in small villages where usually there is no appropriate medical attention, increases the risk of unrecognized transmission of common as well as new or emerging human pathogens. Two-thirds of the world's population live in the less developed countries that lack proper sanitary facilities and a safe drinking water supply, which leads to transmission of enteric pathogens. At least 750 million episodes of diarrhea occur per year in developing countries resulting in five million deaths (Snyder and Mersen 1982).

Genus Hymenolepis, a cyclophyllidean tapeworm, has been described as an infrequent cause of diarrhoea in humans (Beaver et al., 1984). This species was first recognized in the small intestine of a boy in Cairo in 1851 by Bilharz (Al-Hussaini et al., 1979). The two species of genus infecting man, namely Hymenolepis nana (H. nana) and $H$. diminuta, cause diarrhea and abdominal pain only in hosts with heavy infection. Hymenolepis nana is the more common of the two parasites but both 
species have a cosmopolitan distribution.

Hymenolepis nana is easily transmitted directly from person to person. Although $H$. nana has a short life span (a few weeks only), it is easily renewed by new generations of $H$. nana as they complete their life cycle only in human intestine. Hymenolepis nana may cause epidemics in institutions for children. It has also been shown that, $H$. nana infection in mice is profoundly influenced by immunosuppression. This immunosuppression is caused by $\mathrm{T}$-cell deprivation or by induced steroid treatment which results in increased multiplication of abnormal cysticercoids in viscera (WHO 1981). This indirectly suggests that hymenolepsiasis could be another parasitic condition which should be eliminated before initiating immunosuppressive therapy.

$H$. diminuta (rat tapeworm) is a rodent parasite for which arthropods act as intermediate hosts. Eggs ingested by the arthropods develop into cysticercoid larvae. Rodents become infected by ingesting the arthropods. Humans, usually children, can accidentally be infected through the same mechanism. Rodents, particularly rats, are the definitive hosts and natural reservoirs of $H$. diminuta. Coprophilic arthropods (fleas, lepidoptera, and coleoptera) act as intermediate hosts. When an infected arthropod is eaten by the definitive host, the cysticercoids present in its body cavity develop into an adult worm, whose eggs are passed in the stool. It has recently been reported that beetle-to-beetle transmission of $H$. diminuta occurs in natural environments and that eggs can be dispersed in the environment via beetle feces (Pappas and Barley, 1999), thereby representing a source of additional infections and a mechanism of egg dispersal.
H. diminuta infection in humans is uncommon (Levi et al., 1987; Hamrick et al., 1990 and Varghese et al., 1998); only a few hundred cases have been reported (McMillan et al., 1971 ; Tantalean and Caceres 1972; Stafford et al., 1980; Kan et al., 1981; Pampiglione et al., 1987; Tesjaroen et al., 1987 Cohen 1989; Lo et al., 1989; Mercado and Arias 1995 and Tena et al., 1998;). $H$. nana is more commonly reported as a cause of human infection since its transmission does not require any intermediate host and it can be spread directly from person to person(Foresi 1967 and Scaglione et al., 1990). In developed countries, $H$. diminuta infection is very rare and is limited to rural or degraded areas.

Advances in molecular biology techniques have enabled the direct analysis of the nuclear DNA and the mitochondrial DNA of $H$. diminuta and $H$. nana for their genotype identification (Bolla and Roberts 1971; Carter et al., 1972; Henderson and Hanna 1988; Asano et al, 1996; Okamoto et al., 1997 and von Nickisch-Rosenegk et al., 2001). $H$. diminuta and $H$. nana were identified by using the sequence of the nuclear ribosomal internal transcribed spacer 2, ITS2, (Okamoto et al., 1997).

The aim of the present study was to investigate the use of restriction profiles resulting from digestion of the 18S rRNA gene with some restriction endonucleases for separation of the majority Hymenolepis species from Egypt, which would be a step in their genetic map for genotherapy usage.

\section{Material And Methods}

Individuals of the tapeworm $H$. nana and $H$. diminuta were collected from infected rat intestine and preserved in saline solution. The worms were then homogenized in $150 \mu \mathrm{l}$ CTAB 
(cetyltrimethyl-ammonium bromide) buffer using two clean slides and transported to a $1.5 \mathrm{ml}$ eppendorf tube, followed by addition of $450 \mu \mathrm{l}$ CTAB buffer supplemented with $50 \mu \mathrm{g}$ Proteinase $\mathrm{K}$ and incubated at $65^{\circ} \mathrm{C}$ for $2 \mathrm{~h}$. Proteins were removed by extraction with phenol/chloroform, and the DNA was precipitated by adding 50\% (v/v) $7.5 \mathrm{M}$ ammonium acetate and an equal volume of $100 \%$ ethanol. After centrifugation and washing of the pellet with $70 \%$ ethanol, it was dried under a vacuum and resuspended in $50 \mu \mathrm{l}$ $\mathrm{ddH}_{2} \mathrm{O}$ (Rogers and Bendich, 1985 and Doyle and Doyle, 1990). One $\mu 1$ of the resuspended pellet was checked by $0.8 \%$ agarose gel electrophoresis for the presence of DNA, as in Figure 1.

The 18S ribosomal RNA gene of the two species were detected as in Kessing et al. (1989) and Stohard and Rollinson (1997) by using the primers SSU1 (5'-CGACTGGTTGATCCTGC CAGTAG-3') and SSU2 (3'-TCCTG ATCCTCTCAGGTTCAC-5')espective ly. The program of the polymerase chain reaction for amplification of nuclear SrRNA was: 30-35 cycles; one minute, at $94^{\circ} \mathrm{C}$; two to three minutes, at $45^{\circ} \mathrm{C}$; and three minutes, at $72^{\circ} \mathrm{C}$.

HindIII, BglI, EcoRI, BanII (Sigma-Aldrich), SacII (Boehringer Mannheim) and SstII (Life technologies Inc.) restriction endonucleases were used to identify and to differentiate the $18 \mathrm{~S}$ rRNA gene of the two strains of Hymenolepis species. For each digestion reaction, One $\mu \mathrm{l}$ was used together with $1.2 \mu 1$ of the particular enzyme buffer for a final volume of $12.2 \mu \mathrm{l}$. The digestion was performed for $\sim 3.5 \mathrm{~h}$ at $\sim 37^{\circ} \mathrm{C}$, and the digestion products were evaluated on $2 \%$ TBE-agarose gels and stained with ethidium bromide. Restriction patterns were detected upon ultraviolet transillumination and photographed (Awwad and Morsy, in press).

\section{Results}

The nuclear 18S rRNA genes were detected for the two Hymenolepis strains from the PCR products. The nuclear 18S rRNA genes sizes were approximately $2200 \mathrm{bp}$ (Figure 2).

The two species of Hymenolepis did not differentiate when their 18S rRNA genes were digested with HindIII restriction endonuclease (Table 1 and Figure 3: lanes 1 and 2). The result of HindIII digestion of the $H$. nana and $H$. diminuta PCR products gave two restriction fragments for both ( 150 and $2050 \mathrm{bp}$; Table 1 and Figure 3: lanes 1 and 2).

$B g I$ I and EcoRI restriction enzymes differentiated between the two species of Hymenolepis (Tables 2 and 3; Figures 4 and 5). BgII restriction endonuclease cut the 18S rRNA gene of $H$. nana into two restriction bands ( 950 and $\sim 1250 \mathrm{bp}$; Figure 4: lane 1). The same restriction enzyme fragmented the 18S rRNA gene of $H$. diminuta into two fragments ( 900 and $\sim 1300 \mathrm{bp}$; Figure 4: lane 2). The two species of Hymenolepis were differentiated when their 18S rRNA genes were digested with EcoRI restriction endonuclease (Figure 5 and Table 3). EcoRI restriction enzyme gave three restriction fragments $(\sim 50, \sim 200$ and $\sim 1950 \mathrm{bp}$; Figure 5: lane 1) when digested the $18 \mathrm{~S}$ rRNA gene of $H$. nana. Whenever, the same restriction enzyme digested $H$. diminuta 18S rRNA gene into two cuts ( 300 and $\sim 1900$ bp; Figure 5: lane 2).

The 18S rRNA gene of H.nana species were digested uniquely with BanII, SacII and SstII restriction endonucleases without digesting of the $18 \mathrm{~S}$ rRNA of $H$. dimintuta (Figures 6, 7 and 8; Tables 4, 5 and 6, respectively). BanII restriction endonuclease digested the PCR product of $H$. nana into two restriction fragments ( 200 and $\sim 200$ bp; Figure 6: lane 1) without cut the $18 \mathrm{~S}$ rRNA gene of $H$. diminuta (lane 2). 
SscII enzyme gave two restriction bands when digested the 18S rRNA gene of $H$. nana ( 600 and $\sim 1600$ bp; Figure 7 : lane 1) without any fragment with the 18S rRNA gene of $H$. diminuta (lane 2). Also, SstII restriction endonuclease digested $H$. nana $18 \mathrm{~S}$ rRNA gene uniquely into two restriction fragments ( $\sim 650$ and $\sim 1550 \mathrm{bp}$; Figure 8: lane 1) without digestion of the 18S rRNA gene of $H$. diminuta (lane 2).

Table 1: Shows the length of 18Sr RNA genes fragments, resulted from digestion with HindIII enzyme in the two Hymenolepis species.

\begin{tabular}{|l|l|l|l|}
\hline Hymenolepis strain & Band 1 & Band 2 & Band 3 \\
\hline H. nana & $\sim 150$ & $\sim 2050$ & ------ \\
\hline H. diminuta & $\sim 150$ & $\sim 2050$ & ------ \\
\hline
\end{tabular}

Table 2: Shows the length of $18 \mathrm{~S}$ rRNA genes fragments, resulted from digestion with $B g 1$ I enzyme in the two Hymenolepis species.

\begin{tabular}{|l|l|l|l|}
\hline Hymenolepis strain & Band 1 & Band 2 & Band 3 \\
\hline H. nana & $\sim 950$ & $\sim 1250$ & ------ \\
\hline H. diminuta & $\sim 900$ & $\sim 1300$ & ------ \\
\hline
\end{tabular}

Table 3: Shows the length of SrRNA genes fragments, resulted from digestion with EcoRI enzyme in the two Hymenolepis species.

\begin{tabular}{|l|l|l|l|}
\hline Hymenolepis strain & Band 1 & Band 2 & Band 3 \\
\hline H. nana & $\sim 50$ & $\sim 200$ & $\sim 1950$ \\
\hline H. diminuta & $\sim 300$ & $\sim 1900$ & ------ \\
\hline
\end{tabular}

Table 4: Shows the length of SrRNA genes fragments, resulted from digestion with BanII enzyme in the two Hymenolepis species.

\begin{tabular}{|l|l|l|l|}
\hline Hymenolepis strain & Band 1 & Band 2 & Band 3 \\
\hline H. nana & $\sim 200$ & $\sim 2000$ & ------ \\
\hline H. diminuta & ------ & ------ & ------ \\
\hline
\end{tabular}

Table 5: Shows the length of SrRNA genes fragments, resulted from digestion with SacII enzyme in the two Hymenolepis species.

\begin{tabular}{|l|l|l|l|}
\hline Hymenolepis strain & Band 1 & Band 2 & Band 3 \\
\hline H. nana & $\sim 600$ & $\sim 1600$ & ------ \\
\hline H. diminuta & ----- & ------ & ------ \\
\hline
\end{tabular}

Table 6: Shows the length of SrRNA genes fragments, resulted from digestion with SstII enzyme in the two Hymenolepis species.

\begin{tabular}{|l|l|l|l|}
\hline Hymenolepis strain & Band 1 & Band 2 & Band 3 \\
\hline H. nana & $\sim 650$ & $\sim 1550$ & ------ \\
\hline H. diminuta & ------ & ------ & ------ \\
\hline
\end{tabular}


Using Restriction-Site Variation of PCR-Amplified......
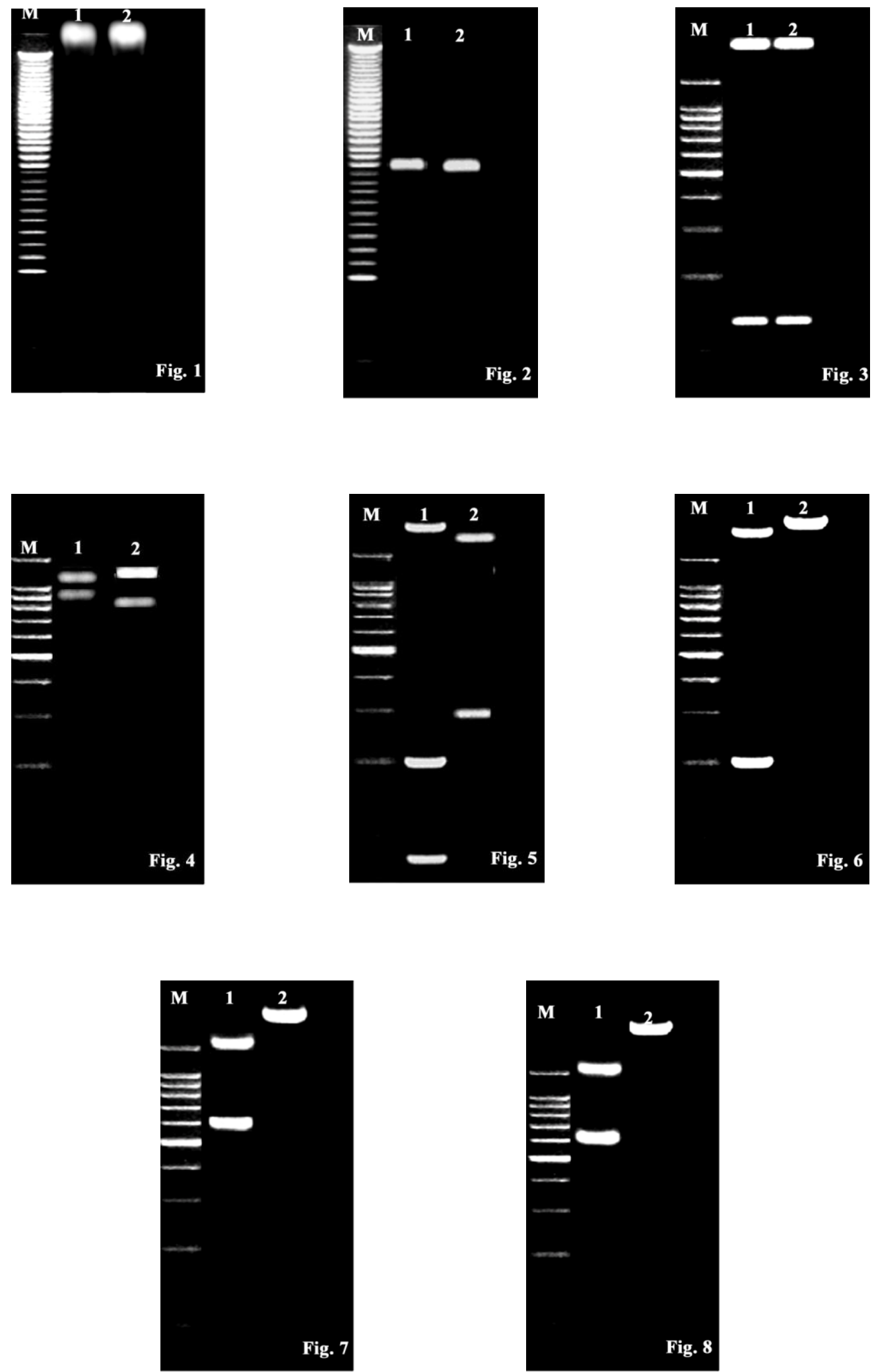
Figure 1: Total DNA genome from Hymenolepis spp. Lane $\mathrm{M}$ is DNA marker (100 - $4000 \mathrm{bp})$. Lanes 1 and 2 represent the DNA of $H$. nana and $H$. diminuta respectively.

Figure 2: Shows full-length of $18 \mathrm{~S}$ rRNA gene ( 2200 bp) of Hymenolepis spp. Lane $\mathrm{M}$ is the DNA marker (100 4000 bp). Lanes 1 and 2 represent the DNA of $H$. nana and $H$. diminuta respectively.

Figure 3: Shows the representative 18S rRNA gene PCR/RFLPs bands from $H$. nana (lane 1) and $H$. diminuta (lane 2) with HindIII restriction endonuclease, which produced the same fragments (two bands: $\sim 150$ and $\sim 2050 \mathrm{bp}$, for both). Lane $\mathrm{M}$ is the DNA marker ( 100 $-1500 \mathrm{bp}$ ).

Figure 4: Shows $B g l \mathrm{I}$ restriction enzyme digested the 18S rRNA gene of $H$. nana into two restriction bands ( 950 and $\sim 1250 \mathrm{bp}$ ) and gave different two restriction patterns in sizes with $H$. diminuta ( 900 and $\sim 1300 \mathrm{bp})$. Lane $\mathrm{M}$ is the DNA marker ( $100-1500 \mathrm{bp}$ ).

Figure 5: Shows EcoRI restriction enzyme digested the 18S rRNA gene of H.nana into three fragments $(\sim 50, \sim 200$ and $\sim 1950 \mathrm{bp}$; lane 1) and the gene of $H$. diminuta into two fragments $(\sim 300$ and $\sim 1900 \mathrm{bp}$; lane 2). Lane $\mathrm{M}$ is the DNA marker ( $100-1500 \mathrm{bp}$ ).

Figure 6: Shows BanII restriction enzyme digested, uniquely, the $18 \mathrm{~S}$ rRNA gene of $H$. nana into two restriction bands ( 200 and $\sim 2000 \mathrm{bp}$; lane 1) and did not react with the gene of $H$. diminuta (lane 2). Lane $\mathrm{M}$ is the DNA marker ( 100 - 1500 bp).

Figure 7: Shows SacII restriction enzyme digested, uniquely, the $18 \mathrm{~S}$ rRNA gene of $H$. nana into two restriction bands $(\sim 600$ and $\sim 1600 \mathrm{bp}$; lane 1) and did not react with the gene of $H$. diminuta (lane 2). Lane $\mathrm{M}$ is the DNA marker ( 100 - 1500 bp).
Figure 8: Shows SstII restriction enzyme digested, uniquely, the $18 \mathrm{~S}$ rRNA gene of $H$. nana into two restriction bands ( 650 and $\sim 1550 \mathrm{bp}$; lane 1) and did not react with the gene of $H$. diminuta (lane 2). Lane $\mathrm{M}$ is the DNA marker ( $100-1500 \mathrm{bp}$ ).

\section{Discussion}

The accurate identification of intestinal helminthes has important implications for many areas, including systematics (taxonomy and phylogeny), population genetics, ecology and epidemiology, and is also central to diagnosis, treatment and control of the diseases they cause. Individual cestodes are frequently identified and distinguished on the basis of morphological features, their transmission patterns or their pathological effects on the host. However, these criteria are often insufficient for specific identification (Lichtenfels et al., 1997 and Andrews and Chilton, 1999). Immunological, biochemical and nucleic acid techniques provide powerful tools to overcome this limitation (McManus and Bowles, 1996 and Andrews and Chilton, 1999). In particular, the advent of the PCR method (Saiki et al., 1985 and Mullis et al., 1986) has revolutionized cestode taxonomy and genetics, mainly because its sensitivity permits the amplification of genes or gene fragments from minute amounts of genomic DNA.

The possibility of using molecular tools for identification of cestodes of medical importance has contributed to increased knowledge of the genus Hymenolepis. The present study demonstrate that PCR-RFLP of the $18 \mathrm{~S}$ rRNA gene of Hymenolepis spp., using HindIII, BglI, EcoRI, BanII, SacII and SstII, permits the differentiation of the majority of the two Hymenolepis species examined. 
HindIII restriction endonuclease couldn't differentiate between the two species of Hymenolepis when digested their 18S rRNA genes and gave the same restriction profiles. HindIII restriction enzyme cut the genes of $H$. nana and $H$. diminuta into similar two restriction fragments. The results of HindIII restriction enzyme digestion may be proved that the two species of Hymenolepis have phylogenetic similarity.

$B g l$ and EcoRI restriction enzymes identified and differentiated $H$. nana and $H$. diminuta when cut their $18 \mathrm{~S}$ rRNA genes into different fragments. $B g l \mathrm{I}$ restriction endonuclease digested the genes of $H$. nana and $H$. diminuta into two different PCR/RFLPs profiles. Also, the $18 \mathrm{~S}$ rRNA genes of $H$. nana and $H$. diminuta were digested with EcoRI restriction enzymes and gave three restriction fragments with $H$. nana and two fragments with $H$. diminuta. The previous results indicated that the two species of Hymenolepis are intra-specific different and polyphylogenetic relationship.

Uniquely, BanII, SacII and SstII restriction endonucleases digested the 18S rRNA gene of $H$. nana without digestion of the same gene of $H$. diminuta. Then, BanII, SacII and SstII restriction endonucleases could be used as molecular marker for identifying $H$. nana.

The sequences of $18 \mathrm{~S}$ rRNA genes of the Hymenolepis species will be analyzed in the future to better understand the intraspecific and interspecific relationships among this species (Okamoto et al., 1997 and von Nickisch- Rosenegk et al., 2001).

The present study shows here that PCR-RFLP is a simple and rapid technique representing an important advance for studies of Hymenolepis species which can be used as a step in genotherapy in the future. The study demonstrated that $18 \mathrm{~S}$ rRNA gene contains useful genetic markers for the genotype identification of these organisms. Also, the results obtained with PCR-RFLP are concordant with the actual morphological systematics proposed for the Hymenolepis species by Beaver et al., (1984). Future investigation must be done to investigate new method for protection of these species.

\section{References}

1. Acha, P.N. and Szyfres, B. (1984): Hymenolepiasis, p. 754-758. In P.N. Acha and B. Szyfres (ed.), Zoonosis y enfermedades transmisibles comunes al hombre y a los animales, 2nd ed. Servicio Editorial de la Organización Panamericana de la Salud, Washington, D.C.

2. Al-Hussaini, M.K.; Khalifa, R.; AlAnsary, A.T.; Hussain, G.H. and Moustafa, K.M. (1979): Phlyctenular eye disease in association with Hymenolepis nana in Egypt. Br. J. Ophthalmol; 63(9): 627-631.

3. Andrews, R.H. and Chilton, N.B. (1999): Multilocus enzyme electrophoresis: a valuable technique for providing answers to problems in parasite systematics. Int. J. Parasitol. 29: 213253.

4. Asano, K.; Muramatsu, K.; Ikeda, K. and Okamoto, K. (1996): Inhibitory action of deoxyspergualin on effector/ memory $\mathrm{T}$ cell generation during Hymenolepis nana infection in mice. Immunol. Lett. 53(1):51- 57.

5. Awwad, M.H. and Morsy, G.H. (in press): Small subunit ribosomal RNA gene identification of the human pathogen Schistosoma spp. in Egypt. Submitted to Egypt. J. Aquat. Biol. \& Fish.

6. Beaver, P.C.; Jung, R.C. and Cupp, E.W. (1984): Cyclophyllidean tapeworms In: Beaver PC (ed.), Clinical Parasitology. Lea \& Febiger, Philadelphia; 511-12.

7. Bolla, R.I. and Roberts, L.S. (1971): Developmental physiology of cestodes. 
X. The effects of crowding on carbohydrate levels and on RNA, DNA and protein synthesis in Hymenolepis diminuta. Comp. Biochem. Physiol. A. 40(3):777-787.

8. Carter, C.E.; Wells, J.R. and Macinnis, A.J. (1972): DNA from anaerobic adult Ascaris lumbricoides and Hymenolepis diminuta mitochondria isolated by zonal centrifugation. Biochim. Biophys. Acta. 262(2):135144.

9. Cohen, I.P. (1989): A case report of Hymenolepis diminuta in a child in $\mathrm{St}$ James Parish, Jamaica. J. La. State Med. Soc. 141:23-24.

10. Doyle, J.J. and Doyle, J.L. (1990): Isolation of plant DNA from fresh tissue. Focus. 12: 13-20.

11. Foresi, C. (1967): Data on the epidemiology of hymenolepiasis in Italy. Arch. Ital. Sci. Med. Trop. Parasitol. 48:251262.

12. Gagandeep, K. ; Mathew, M.S.; Rajan, D.P.; Daniel, J.D.; Mathan, M.M.; Mathan, V.I. and Muliyil, J.P. (1998): Prevalence of intestinal parasites in rural Southern Indians. Trop. Med. Int. Health. 3(1): 70-75.

13. Hamrick, H.J.; Bowdre, J.H. and Chrurch, S.M. (1990): Rat tapeworm: Hymenolepis diminuta infection in a child. Pediatr. Infect. Dis. J. 9:216-219.

14. Henderson, D.J. and Hanna, R.E. (1988): Hymenolepis nana (Cestoda: Cyclophyllidea): DNA, RNA and protein synthesis in 5-day-old juveniles. Int. J. Parasitol. 18(7):963-972.

15. Kan, S.K.; Kok, R.T.; Marto, S.; Thomas, I. and Teo, W.W. (1981): The first report in Hymenolepis diminuta infection in Sabah, Malaysia. Trans. R Soc. Trop. Med. Hyg. 75:609.

16. Kessing, B.; Croom, H.; Martin, A.; McIntosh, C.; McMillan, W.O. and Palumbi, S. (1989): The Simple Fool's Guild to PCR (S. Palumbi And C. Simon lab manual).

17. Levi, M.H.; Raucher, B.G.; Teicher, E.; Sheehan, D.J. and McKitrick, J.C. (1987): Hymenolepis diminuta: one of three pathogens isolated from a child. Diagn. Microbiol. Infect. Dis. 7:255-259.

18. Lichtenfels, J.R.; Hoberg, E.P. and Zarlenga, D.S. (1997): Systematics of gastrointestinal nematodes of domestic ruminants: advances between 1992 and 1995 and proposals for future research. Nucl. Acids Res. 18: 4123-4130.

19. Lo, C.T.; Ayele, Y. and Birrie, H. (1989): Helminth and snail survey in Harerge region of Ethiopia with special reference to schistosomiasis. Ethiop. Med. J. 27:73-83.

20. McManus, D.P. and Bowles, J. (1996): Molecular genetic approaches to parasite identification: their value in diagnostic parasitology and systematics. Int. J. Parasitol. 26: 687-704.

21. McMillan, B.; Kelly, A. and Walker, J.C.(1971): Prevalence of Hymenolepis diminuta infection in man in the New Guinea Highlands. Trop. Geogr. Med. 23:390-392.

22. Mercado, A. and Arias, B. (1995): Taenia sp. and other intestinal cestode infections in individuals from public outpatient clinics and hospitals from the northern section of Santiago, Chile (1985-1994). Bol. Clin. Parasitol. 50:80-83.

23. Mullis, K.B.; Faloona, F.; Scharf, S.; Saiki, R.; Horn, G. and Erlich, H. (1986): Specific enzymatic amplification of DNA in vitro: the polymerase chain reaction. Cold Spring Harbor Symposium of Quantitative Biology. 51: 263-273.

24. Okamoto, M.; Agatsuma, T.; Kurosawa, T. and Ito, A. (1997): Phylogenetic relationships of three hymenolepidid species inferred from nuclear ribosomal and mitochondrial DNA sequences. Parasitology. 115 ( Pt 6):661-666.

25. Pampiglione, S.; Visconti, S. and Pezzino, G. (1987): Human intestinal parasites in Subsaharan Africa. II. Sao Tome and Principe. Parasitologia 29:15-25.

26. Pappas, P.W. and Barley, A.J. (1999): Beetle-to-beetle transmission and dispersal of Hymenolepis diminuta 
(Cestoda) eggs via the feces of Tenebrio molitor. J. Parasitol. 85:384-385.

27. Rogers, S.R. and Bendich, A.J. (1985): Extraction of DNA from milligram amounts of fresh, herbarium and mummified plant tissues. Plant Mol. Biol. 5: 69-77.

28. Scaglione, L.; Troielli, F.; Ansaldi, E.; Orsi, P.G. and Garavelli, P.L. (1990): Hymenolepis diminuta: a rare helminthiasis in humans. Description of a clinical case. Minerva Med. 81:6567.

29. Snyder, J.D.and Mersen, M.H. (1982): The magnitude of the global problem of acute diarrheal disease : a review of active surveillance data. Bull WHO; 60: 605-13.

30. Stafford, E.; Sudomo, E.M.; Marsi, S. and Brown, R.J. (1980): Human parasitosis in Bali, Indonesia. Southeast Asian J. Trop. Med. Public Health. 11:319-323.

31. Stohard, J.R.; Rollinson, D. (1997): Molecular characterization of Bulinus globosus and B. nasutus on Zanzibar, and an investigation of their roles in the epidemiology of Schistosoma haematobium. Trans. R. Soc. Trop. Med. Hyg., 91: 353-357.

32. Tantaleán, Z. and Cáceres, I. (1972): Hospedadores intermediarios de Hymenolepis diminuta en Lima (Peru'). Rev. Peru. Med. Trop. 22:27.
33. Tena, D.; Perez Simon, M.; Gimeno, M.; Perez Pomata, M.T.; Illescas, S.; Amondarain, I.; Gonzalez, A.; Dominguez, J. and Bisquert, $J$. (1998): Human infection with Hymenolepis diminuta: case report from Spain. J. Clin. Microbiol. 36:2375-2376.

34. Tesjaroen, S.; Chareonlarp, K.; Yoolek, A.; Mai-iam, W. and Lertlaituan, P. (1987): Fifth and sixth discoveries of Hymenolepis diminuta in Thai people. J. Med. Assoc. Thail. 70:49-50.

35. Varghese, S.L.; Sudha, P.; Padmaja, P.; Jaiswal, P.K. and Kuruvilla, T. (1998): Hymenolepis diminuta infestation in a child. J. Commun. Dis. 30:201-203.

36. von Nickisch-Rosenegk, M.; Brown, W.M. and Boore, J.L. (2001): Complete sequence of the mitochondrial genome of the tapeworm Hymenolepis diminuta: gene arrangements indicate that Platyhelminths are Eutrochozoans. Mol. Biol. Evol. 18(5):721-730.

37. World Health Organization (1981): Intestinal protozoan and helminthic infections. Report of a WHO Scientific Group. WHO TRS; 666: 86.

38. World Health Organization (1987): Prevention and control of intestinal parasitic infections. WHO Technical Reports Series, No749, 1-86. 


\section{استخدام التغاير فى أماكن القطع للجين 18س الريبوزومى التاتج بطريقة

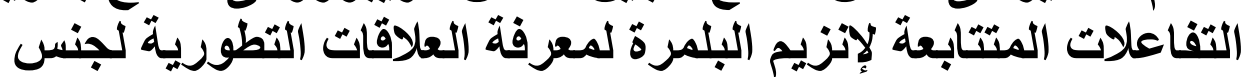

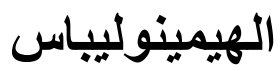

\section{محمد حسين عواد, جيهان حسين لاشين وسحر محمد أبو الخير

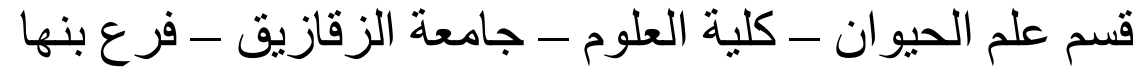

إن الطفيليات المعوية والتى تعيش فى الجهاز الهضدى بصفة عامـة و الأمعاء بصفة

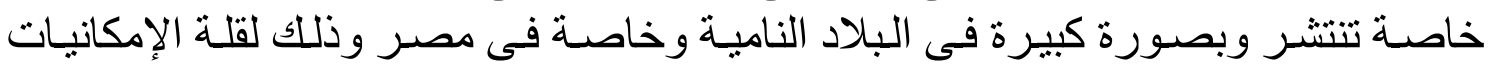
المعملية والتشخيصية وكذلك الجهل الطبى للناس. إن جنس الهيمينوليباس بعتبر من فن الديدان

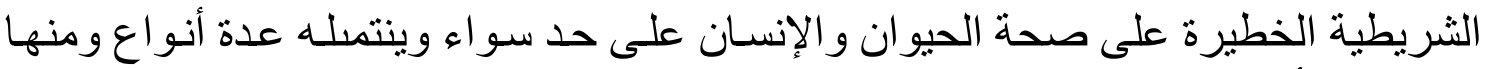

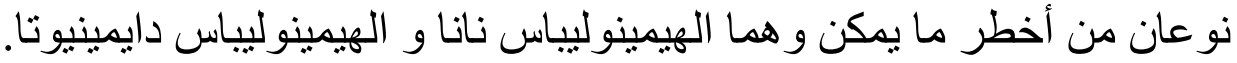

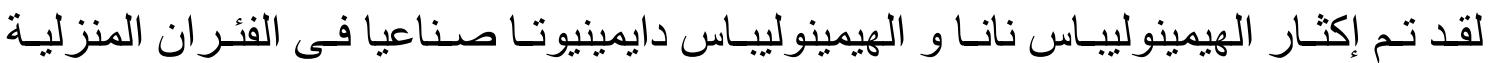

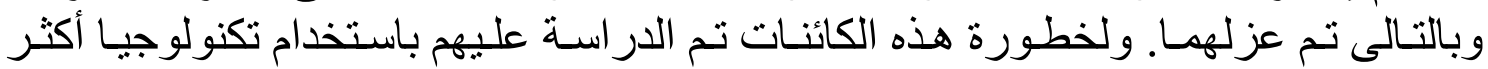
تطورا كاستخدام تقنية التغاير فى طول القطع المحددة لجين 18س الريبوزورمى للتفرقة بين

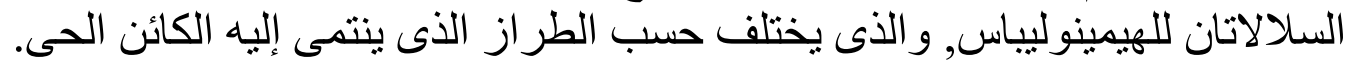
وقد تم عن طريق الفصل الكهربى استخلاص جينات ال18س الريبوزمى من النواة بطريقة

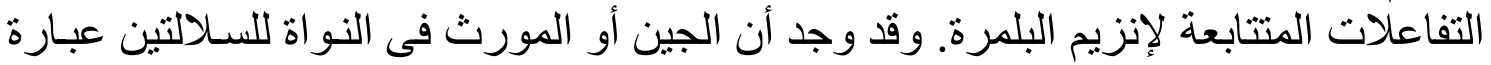

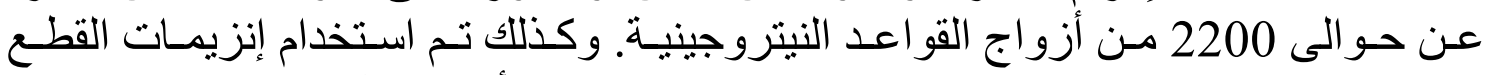
SstII SacII, BanII, EcoRI, Bg1I,HindIII المورث لكلا النو عين وذلك لتعيين أوجه الاختلافات الور اثية بينها.

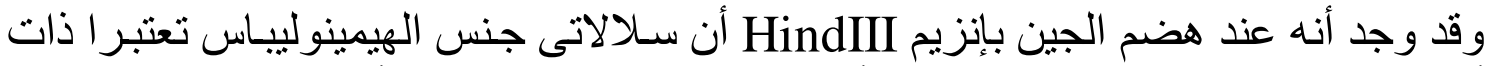
أصل ور اثى و احد. فعند هضم الجين (أو المورث) بإنزيم HindIII أعطت قطعتين (حو الى

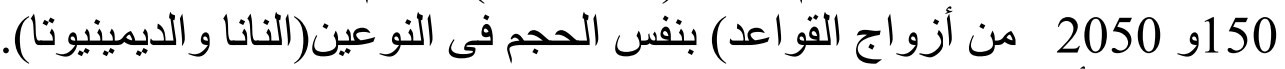

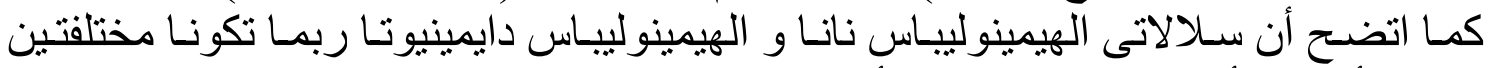

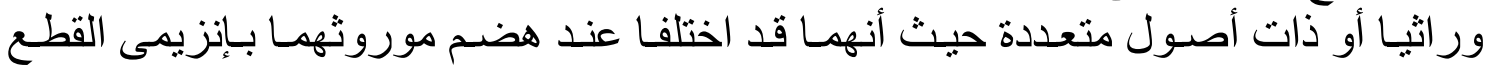
EcoRIوBg1I

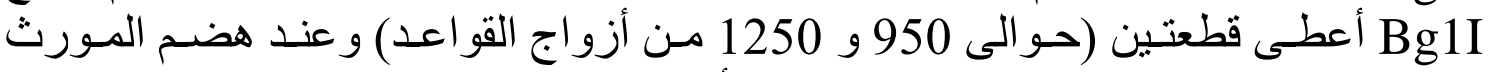

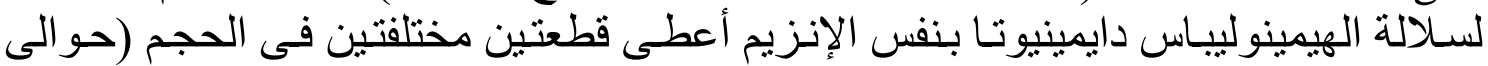

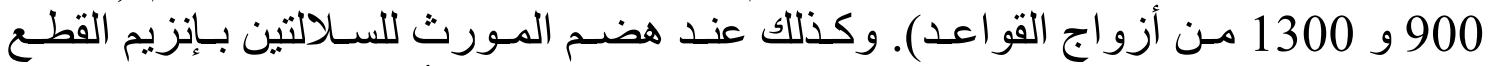
EcoRI

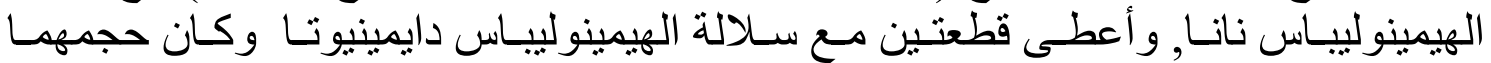
(حو الى 300 و 1900 من أزو اج القواعد). و على هذا فربما تكونا سلالتى الهيمينوليباس نانا

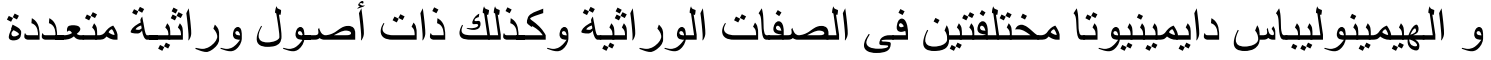
و وختلفة.

إنه من الممكن استخدام أنواع معينة من إنزيمات القطع كمجسات لتعبين أو معرفة نوع معين

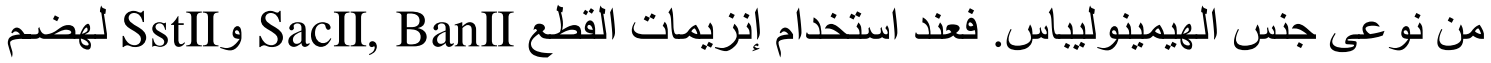
جين ال18س الريبوزمى لســلالتى الهيمينوليبـاس نانـا و الهيمينوليبـاس دايمينيوتـا فلـم يـتـم 


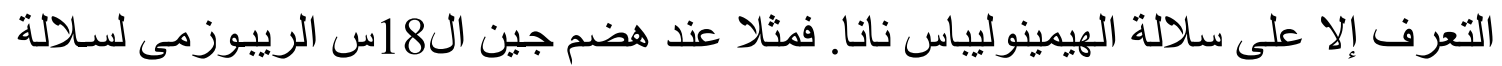

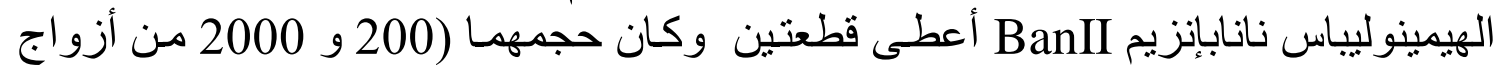

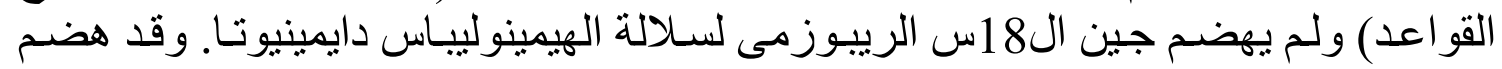
إنزيم SacII جين ال180)

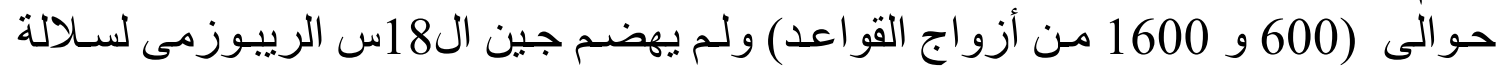

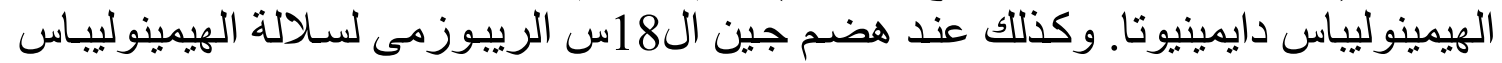

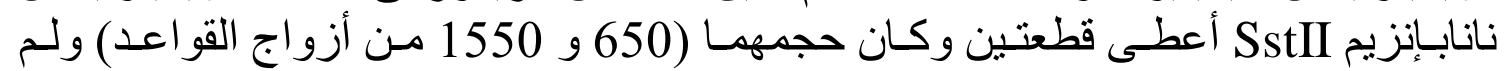

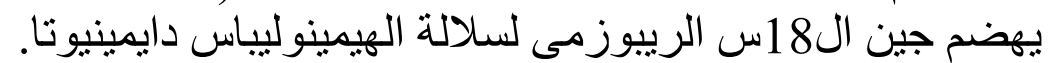

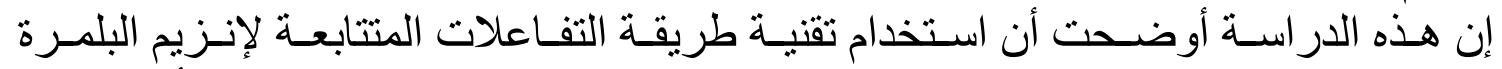

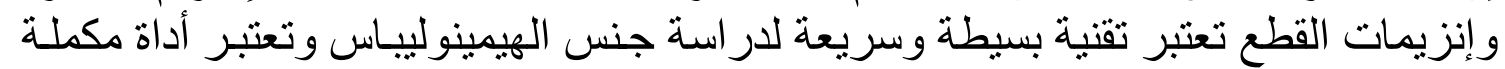

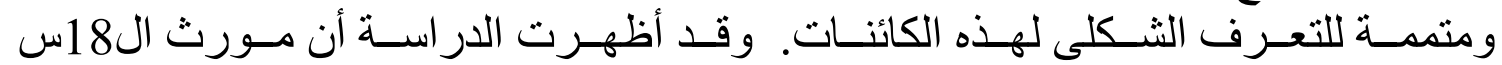

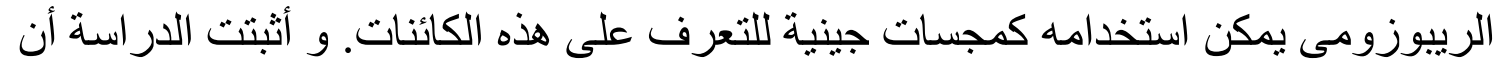

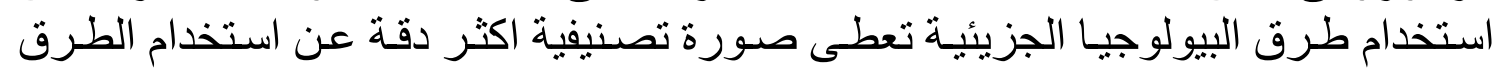

